\title{
Uji Toksisitas Ekstrak Biji Kelor (Moringa Oleifera) Terhadap Larva Nyamuk Aedes Aegypti
}

\section{Toxicity Test Of Moringa Seed Extract (Moringa Oleifera) Extract On Aedes Aegypti Mosquito Larvae}

\author{
Neneng Bisyaroh \\ Program Studi Farmasi, Fakultas Ilmu Kesehatan, Universitas Ibrahimy \\ Email: neneng@ibrahimy.ac.id
}

\begin{abstract}
ABSTRAK
Di Indonesia banyak memiliki tanaman yang memiliki kandungan senyawa metabolit sekunder yang dapat menjadi sumber bahan insektisida nabati yang dapat dimanfaatkan untuk pengendalian vektor. Tanaman yang dapat digunakan sebagai larvasida nabati antara lain yaitu ekstrak biji kelor mengandung senyawa metabolit sekunder berupa senyawa alkaloid dan senyawa fenolik yaitu saponin dan tannin. Senyawa-senyawa tersebut bersifat larvasida terhadap larva Aedes aegypti. Tujuan penelitian ini untuk Tujuan dari penelitian ini yaitu untuk mengetahui tingkat toksisitas dari ekstrak biji kelor (Moringa oleifera) terhadap mortalitas larva nyamuk Aedes aegypti. Jenis penelitian ini adalah penelitian eksperimental laboratoris dengan pendekatan Post test only control group, menggunakan 6 kelompok (kelompok kontrol negatif, ekstrak biji kelor 500 ppm, ekstrak biji kelor 750 ppm, ekstrak biji kelor 1000 ppm, ekstrak biji kelor 1250 ppm, dan ekstrak biji kelor 1500 ppm). Penelitian ini diperoleh hasil yaitu ekstrak biji kelor (Moringa oleifera) memiliki efek larvasida terhadap larva Aedes aegypti instar III/IV jumlah kematian larva Aedes aegypti instar III/ IV memperlihatkan bahwa jumlah kematian larva tertinggi terdapat pada konsentrasi 1500 ppm yaitu sebanyak 15,66 ekor (62,64\%) sedangkan nilai terendah terdapat pada konsentrasi 500 ppm dengan larva yang mati sebanyak 3,33 ekor $(13,32 \%)$.
\end{abstract}

Kata Kunci: Biji Kelor, Toksisitas, Larva Aedes aegypti

\begin{abstract}
In Indonesia, there are many plants that contain secondary metabolite compounds which can be a source of vegetable insecticides which can be used for vector control. Plants that can be used as vegetable larvicides include moringa seed extract containing secondary metabolites in the form of alkaloids and phenolic compounds, namely saponins and tannins. These compounds are larvicidal against Aedes aegypti larvae. The purpose of this study was to determine the level of toxicity of Moringa oleifera seed extract to mortality of Aedes aegypti mosquito larvae. This type of research is a laboratory experimental study with a post test only control group approach, using 6 groups (negative control group, 500 ppm moringa seed extract, 750 ppm moringa seed extract, 1000 ppm moringa seed extract, 1250 ppm moringa seed extract, and $1250 \mathrm{ppm}$ seed extract. moringa $1500 \mathrm{ppm}$ ). The results showed that the extract of Moringa oleifera seeds had a larvicidal effect on 3rd / IV instar Aedes aegypti larvae. 62.64\%) while the lowest value was at a concentration of 500 ppm with 3.33 dead larvae (13.32\%).
\end{abstract}

Keywords: Moringa seeds, toxicity, Aedes aegypti larvae

\section{PENDAHULUAN}

Deman berdarah dengue (DBD) merupakan penyakit yang disebabkan oleh virus dengue yang tergolong dalam family Flaviviridae (Athropod-borne virus). Persebaran penyakit ini banyak ditemukan di daerah dengan iklim tropis dan sub tropis, terutama Asia 
menempati urutan pertama dengan jumlah penderita DBD tertinggi setiap tahunnya. Pada tahun 2001-2007 lebih dari 30 negara di Amerika sudah mencapai 4.332.731 kasus penderita DBD (KemenKes, 2015).

Salah satu penyakit yang terjadi di Indonesia adalah demam berdarah. Beberapa kurun waktu peyakit DBD ini kasusnya cenderung meningkat bahkan dapat menyebabkan kematian hingga terulangnya kembali kejadian luar biasa (KLB). Data dari Kemenkes RI pada tahun 2017 menunjukkan kasus DBD dapat mencapai 68.407 kasus dengan jumlah kematian 493 orang. Namun, jumlah tersebut mengalami penurunan dari tahun sebelumnya ang mencapai 204.171 kasus dan angka kematian 1.598 orang. Perbandingan angka kasus penderita DBD pada tahun 2017 menurun dari pada tahun 2016 yaitu 78.85 menjadi 26.01 dalam populasi penduduk 100 orang. Oleh karena itu, perlu adanya tindakan pencegahan untuk menekan angka penderita DBD (DinKes NTT, 2013).

Upaya penanggulangan DBD sudah dilakukan sejak tahun 1968 dan dilaksanakan secara berlanjut hingga tahun 1974. Saat ini vaksin dan obat untuk mencegah dan membunuh virus
Dengue belum ditemukan sehingga upaya pemberantasan vektor DBD hanya dapat dilakukan dengan memberantas telur, larva, dan nyamuk dewasanya saja. Pemberantasan larva nyamuk sangat penting dilakukan dikarenakan nyamuk betina setiap bertelur menghasilkan sebanyak 100 butir telur. Apabila larva tersebut tidak dibasmi maka akan terjadi peningkatan nyamuk dewasa. Oleh sebab itu, penanggulangan dengan cara memutus siklus hidup nyamuk pada fase larva merupakan salah satu pengendalian vektor DBD yang lebih efisien dan efektif (KemenKes, 2015).

Cara yang dianggap paling efektif dalam pemberantasan jentik nyamuk dengan menggunakan insektisida kimia. Namun, penggunaan bahan kimia menimbulkan dampak negatif bagi lingkungan dan resistensi serangga sasaran. Solusi dalam menanggulangi dampak negatif tersebut dilakukanlah cara mengatasi dampak dengan cara beralih menggunakan insektisida hayati yang berasal dari tanaman. Kandungan bahan kimia dari insektida hayati yang toksik terhadap serangga dan mudah terurai di alam sehingga bersifat ramah lingkungan dan makhluk hidup lain (Kardinan A. 2003). 
Di Indonesia banyak memiliki tanaman yang memiliki kandungan senyawa metabolit sekunder yang dapat menjadi sumber bahan insektisida nabati yang dapat dimanfaatkan untuk pengendalian vektor. Tanaman yang dapat digunakan sebagai larvasida nabati antara lain yaitu serai dapur (Cymbopogon citratus) yang mengandung senyawa metabolit yaitu tannin dan saponin. Daun sirih hijau (Pipper betle. Linn) mengandung senyawa saponin, tannin, flavonoid, steroid, alkaloid dan minyak atsiri dengan nilai LC50 0,108\%. Beberapa senyawa tersebut berfungsi sebagai larvasida dan dapat menyebabkan kematian terhadap larva Aedes aegypti. Salah satu tanaman yang memiliki fungsi larvasida adalah kelor. Putra, et. al., 2016 menyebutkan bahwa bagian tanaman kelor yang dimanfaatkan yaitu daun, kulit batang dan bijinya. Kandungan senyawa kimia pada daun kelor antara lain flavonoid, steroid, fenol, triterpenoid, tannin, alkaloid, saponin dan hidrokuinon (Kiswandono, 2010).

Berdasarkan penelitian Oliveira menunjukkan bahwa biji kelor memiliki sumber lektisida sebagai larvasida yang memiliki potensi tinggi untuk mengendalikan larva Aedes aegypti. Rahayu menyatakan bahwa ekstrak biji kelor mengandung senyawa alkaloid dan fenolik (saponin dan tannin). Selain itu berdasarkan penelitian Manurung menunjukkan ekstrak etanol biji kelor mengandung senyawa metabolit sekunder lain seperti steroid/triterpenid, flavonoid dan glikosida. Hal tersebut menunjukkan bahwa biji kelor mampu bermafaat sebagai larvasida dan memiliki potensi sebagai alternatif pengendalian vektor DBD.

Tujuan penelitian ini untuk mengetahui tingkat toksisitas dari ekstrak biji kelor (Moringa oleifera) terhadap mortalitas larva nyamuk Aedes aegypti.

\section{METODE PENELITIAN}

Jenis penelitian ini adalah eksperimental laboratoris dengan pendekatan Post test only control group, menggunakan 6 kelompok ekstrak biji kelor dengan berbagai konsentrasi (kontrol negatif, 500 ppm, 750 ppm, 1000 ppm, 1250 ppm, dan 1500 ppm).

Penelitian ini dilakukan di Laboratorium Kimia Farmasi Program Studi Farmasi Fakultas Ilmu Kesehatan, Universitas Ibrahimy. Penelitian ini 
dilakukan pada bulan Septemer 2018Februari 2019.

Alat yang digunakan anatara lain pipet volume, labu takar, neraca analitik, rotary evaporator, blender, beaker glass, gelar ukur, pengaduk, cawan porselen, pisau, nampan plastic,pipet, toples plastic, kain, label, sarung tangan. Bahan yang digunakan adalah biji kelor, etanol, akuades, larutan Na-CMC, larva Aedes aegypti instar 4, pakan larva.

Metode pada penelitian ini adalah larva Aedes aegypti instar III/IV yang diperoleh dari area penampungan air di sekitar Fakultas Ilmu Kesehatan Universitas Ibrahimy. Sampel yang digunakan 25 ekor sesuai dengan rekomendasi WHO. Larva dimasukkan dalam 6 wadah perlakuan. Setiap wadah berisi 25 ekor larva. Selanjutnya direplikasi atau pengulangan perlakuan sebanyak 3 kali. Sehingga, jumlah seluruh besar sampel adalah jumlah sampel total 450 larva.

Bahan yang digunakan adalah simplisia biji kelor (Moringa oleifera) yang dikoleksi dari area Banyuputih. Biji kelor yang digunakan sebanyak 870 gram selanjutnya dilakukan proses sortasi, pencucian, pengeringan, penghalusan dan penyaringan sehingga diperoleh 450 gram serbuk kering biji kelor.

Ekstraksi Serbuk kering biji kelor sebanyak 450 gram yang telah di peroleh dari proses sebelumnya dimaserasi dengan pelarut etanol $70 \%$ selama 7 hari. Pemekatan ekstrak dilakukan di Laboratorium Biosains Undana pada hari ke-8 dengan alat rotary evaporator pada suhu $45^{\circ} \mathrm{C}$. Ekstrak kental yang diperoleh dari rangkaian prosedur ekstraksi adalah sebesar 44,7186 gram.

Data hasil pengamatan uji toksisitas terhadap mortalitas dianalisis dengan menggunakan uji analisis varian perbedaan nilai kelompok kontrol dan perlakuan menggunakan Anova Satu Arah (One Way Anova) dan dilanjutkan dengan Uji Least Significance Difference (LSD) dengan tingkat kepercayaan $\quad 95 \% \quad(\alpha=0,05)$ menggunakan program SPSS 16.0 for Windows Evaluation Version. 


\section{HASIL DAN PEMBAHASAN}

Tabel 1 Jumlah Kematian larva Aedes aegypti setelah 48 jam perlakuan

\begin{tabular}{ccccccc}
\hline \multirow{2}{*}{ Replikasi } & \multicolumn{6}{c}{ Kelompok } \\
& K1 & K2 & K3 & K4 & K5 & K6 \\
\hline I & 0 & 3 & 5 & 8 & 11 & 14 \\
II & 0 & 4 & 5 & 9 & 12 & 16 \\
III & 0 & 3 & 7 & 11 & 14 & 17 \\
Jumlah & 0 & 10 & 17 & 28 & 38 & 47 \\
Rata-rata & 0 & 3.33 & 5.66 & 9.33 & 12.66 & 15.66 \\
$\begin{array}{c}\text { Presentase } \\
(\%)\end{array}$ & 0 & 13.32 & 22.64 & 37.32 & 50.64 & 62.64 \\
\hline
\end{tabular}

Jangka waktu penelitian uji efektivitas ekstrak biji kelor terhadap larva Aedes aegypti instar III/ IV dilakukan selama 48 jam untuk melihat efek larvasida. Hasil pengamatan dan perhitungan jumlah kematian larva Aedes aegypti instar III/ IV pada Tabel 1 diatas memperlihatkan bahwa jumlah kematian larva tertinggi terdapat pada konsentrasi 1500 ppm yaitu sebanyak 15,66 ekor $(62,64 \%)$ sedangkan nilai terendah terdapat pada konsentrasi 500 ppm dengan larva yang mati sebanyak 3,33 ekor (13,32\%). Pada kelompok kontrol negatif pada semua replikasi tidak ditemukan adanya larva yang mati.

Tabel 2 Hasil Uji Normalitas KolmogorovSmirnov

\begin{tabular}{|c|c|c|c|}
\hline & Mean & $\begin{array}{c}\text { Asymp. Sig. } \\
\text { (2-tailed) }\end{array}$ & Keterangan \\
\hline $\begin{array}{c}\text { Jumlah larva } \\
\text { mati }\end{array}$ & 7.78 & 0.200 & $\begin{array}{c}\text { Distribusi } \\
\text { normal }\end{array}$ \\
\hline $\begin{array}{c}\text { Konsentrasi } \\
\text { Ekstrak }\end{array}$ & 833.33 & 0.200 & $\begin{array}{c}\text { Distribusi } \\
\text { normal }\end{array}$ \\
\hline
\end{tabular}

Pada Tabel 2 hasil uji normalitas menunjukkan bahwa massing-masing nilai signifikannya adalah 0,200 (p > 0,05), maka dapat disimpulkan bahwa data berdistribusi normal.

Tabel 3 Hasil Uji One Way ANOVA

\begin{tabular}{ll}
\hline & $\mathbf{P}$ \\
\hline Between Groups & $0.000 *$
\end{tabular}

Keterangan: Uji One Way ANOVA dengan $\alpha=0,05 ; *=$ terdapat perbedaan yang bermakna.

Untuk mengetahui perbedaan jumlah kematian larva terhadap perbedaan pada masing-masing konsentrasi uji, maka dilakukan uji One-Way ANOVA. Pada Tabel 3 menunjukkan bahwa nilai nilai $\mathrm{p}=0,000$ ( $\mathrm{p}<0,05)$, maka dapat disimpulkan bahwa paling tidak terdapat perbedaan jumlah kematian larva Aedes aegypti antara dua kelompok perlakuan.

Tabel 4 Hasil Uji Post Hoc dengan LSD

\begin{tabular}{|c|c|c|c|}
\hline \multirow{2}{*}{ Jumlah } & \multirow{2}{*}{$\mathrm{K} 1 \mathrm{vs}$} & \multirow{2}{*}{ K2 } & \multirow{2}{*}{$\begin{array}{c}\mathbf{P} \\
0,005^{*}\end{array}$} \\
\hline & & & \\
\hline & & K3 & $0,000 *$ \\
\hline & & K4 & $0,000^{*}$ \\
\hline & & K5 & $0,000^{*}$ \\
\hline & & K6 & $0,000^{*}$ \\
\hline
\end{tabular}

Keterangan: Uji Post Hoc dengan LSD menggunakan $\alpha=0,05 ; *=$ terdapat perbedaan yang bermakna.

Untuk mengetahui kelompok uji mana yang mempunyai perbedaan secara signifikan maka dilakukan uji analsis Post Hoc. Alat untuk melakukan analisis Post Hoc untuk One Way 
ANOVA adalah uji Least Significance Difference (LSD). Hasil uji ini tercantum pada Tabel 4. Pada Tabel 4 hasil analisis uji ini menunjukkan bahwa semua kelompok uji berbeda secara signifikan terhadap kelompok kontrol negatif dengan nilai $\mathrm{p}<0,05$ yaitu konsentrasi $500 \mathrm{ppm}(\mathrm{p}=0,005)$, 750 ppm $\quad(\mathrm{p}=0,005), \quad 1000 \quad \mathrm{ppm}$ $(\mathrm{p}=0,000), 1250 \mathrm{ppm}(\mathrm{p}=0,000)$, dan 1500 ppm ( $\mathrm{p}=0,000)$. Pada hasil uji ini dapat disimpulkan bahwa konsentrasi minimal efektif yang dapat membunuh larva adalah 500 ppm.

Tabel 5 Hasil Analisis Probit

\begin{tabular}{cccc}
\hline Probability & \multicolumn{3}{c}{ 95\% Confidence Limits for } \\
& \multicolumn{3}{c}{ konsentrasi } \\
\cline { 2 - 4 } & Estimate & Lower & Upper \\
& & Bound & Bound \\
$\mathbf{0 , 5 0 0}$ & 1041,788 & - & - \\
$\mathbf{0 , 9 9 0}$ & 11000,920 & - & - \\
\hline
\end{tabular}

Untuk mengetahui konsentrasi yang dibutuhkan untuk mematikan 50\% (LC50) dan 99\% (LC99) populasi larva selama 48 jam, maka dilakukan uji analisis Probit dengan menggunakan software yang sesuai. Hasil perhitungan analisis Probit didapatkan hasil seperti yang ditunjukkan pada Tabel 5 . Berdasarkan Tabel 5 hasil dari uji ini didapatkan nilai LC50 adalah 1041 ppm yang artinya dibutuhkan konsentrasi ekstrak biji kelor dengan nilai 1041 ppm untuk membunuh $50 \%$ populasi larva. Kemudian dari hasil analisis Probit juga didapatkan nilai LC99 adalah 11000 ppm yang artinya dibutuhkan konsentrasi ekstrak biji kelor sebesar 11000 ppm untuk membunuh $99 \%$ populasi larva.

Pengaruh pemberian ekstrak biji Moringa oleifera terhadap mortalitas larva Aedes aegypti instar III/IV menunjukkan aktivitas larvasida dengan nilai Lethal Concentration (LC). Nilai LC50 merupakan konsentrasi larutan uji yang menyebabkan kematian $50 \%$ pada hewan uji. Hasil analisis Probit pada penelitian ini menunjukan nilai LC50 sebesar 1041 ppm. Hal ini menunjukkan bahwa dibutuhkan konsentrasi ekstrak biji kelor dengan nilai 1041 ppm untuk membunuh $50 \%$ populasi larva. Jika nilai LC semakin rendah maka menunjukkan zat tersebut memiliki aktivitas larvasida yang kuat. Hal dikarenakan zat tersebut perlu konsentrasi jauh yang lebih rendah untuk mematikan hewan uji dalam waktu yang sama. Suatu ekstrak yang berasal dari tanaman bisa memiliki nilai LC50 yang berbeda-beda. Perbedaan nilai LC50 ini diduga diakibatkan oleh perbedaan ketahanan larva sebagai bahan uji. 
Selain itu, faktor-faktor dari tanaman juga dapat berpengaruh seperti lokasi tumbuh asal tanaman, periode pemanenan, Ekstrak biji kelor memiliki kemampuan aktivitas larvasida jauh lebih baik jika dibandingkan dengan ekstrak etanol daun mimba (Azadirachta indica) yang memiliki nilai LC50 8.236 ppm.

Hal ini didukung dengan penelitian ini, hasil penelitian yang dilakukan oleh Coelho dkk pada tahun 2009 menunjukkan ekstrak aquades biji kelor memiliki kemampuan membunuh larva Aedes aegypti instar IV dan menghambat pertumbuhan larva hingga mencapai tahap instar III. Selain spesies nyamuk Aedes aegypti kemampuan larvasida ekstrak biji kelor juga banyak di teliti terhadap larva spesies nyamuk lain. Berdasarkan penelitian Prabhu dkk pada tahun 2011 yang menggunakan ekstrak aseton biji kelor menunjukkan adanya kematian larva dan pupa Anopheles stephensi yang diduga disebabkan oleh senyawa metabolit sekunder seperti fenolat, terpinoid dan alkaloid.

Menurut Rattan pada tahun 2010, mekanisme kerja insektisida senyawa metabolit sekunder yang berasal dari tumbuhan adalah sebagai berikut, Menghambat AChE; Menghambat saluran klorida GABA; Menghambat sistem mitokondria; dan Memblokir reseptor Octopamine (OA). Penelitian sebelumnya yang dilakukan oleh Nepolean dkk pada tahun 2009, serta penelitian kajian potensi biji kelor yang dilakukan oleh Rahayu pada tahun 2011, menunjukkan ekstrak biji kelor mengandung berbagai senyawa metabolit sekunder berupa senyawa alkaloid dan senyawa fenolik yaitu saponin dan tanin. Selain itu berdasarkan hasil skrining fitokimia ekstrak etanol biji kelor yang dilakukan dalam penelitian Manurung, 2016, menunjukan terdapat kandungan senyawa metabolit sekunder lain seperti steroid/triterpenoid, flavonoid, dan glikosida. Etanol yang dipakai sebagai pelarut dalam penelitian ini kemungkinan dapat menyari senyawasenyawa tersebut.

Saponin merupakan senyawa bioaktif yang bersifat toksik dan termasuk golongan racun kontak. Efek senyawa saponin dapat menurunkan tegangan permukaan selaput mukosa traktus digestivus pada larva, sehingga bagian dindingnya menjadi korosif dan gangguan pada proses metabolisme (Cania, 2013). Selain itu, saponin dapat 
merusak membran kutikula hingga menyebabkan kematian pada larva. Bagavan, 2008 menyatakan bahwa saponin yang diisolasi dari Achyranthes aspera berfungsi sebagai larvasida terhadap Aedes aegypti dan C.quinquefasciatus.

Mekanisme kerja alkaloid dengan cara menghambat kerja enzim AchE yang mengakibatkan terjadi penumpukan asetilkolin sehingga menyebabkan kekacauan pada sistem penghantaran impuls ke sel-sel otot. Senyawa alkaloid juga dapat mendegradasi membran sel untuk masuk ke dalam, merusak sel, mengganggu sistem kerja saraf larva. Hal ini berakibat pada larva mengalami kekejangan secara terusmenerus dan akhirnya terjadi kelumpuhan dan jika kondisi ini berlanjut terus dapat menyebabkan kematian larva. Senyawa alkaloid dapat menyebabkan perubahan warna pada tubuh larva menjadi lebih transparan dan gerakan tubuh larva yang melambat dengan adanya rangsang sentuhan dengan posisi selalu membengkokkan badan.

Senyawa aktif lain yang terkandung dalam biji kelor adalah flavonoid yang berperan sebagai inhibitor kuat pernafasan atau sebagai racun pernafasan. Mekanisme kerja senyawa ini yaitu dengan masuk ke dalam tubuh larva melalui sistem pernapasan kemudian menimbulkan kelayuan pada syaraf serta ganguan terhadap sistem pernapasan. Akibat gangguan tersebut larva tidak bisa bernapas hingga akhirnya mati. Posisi tubuh larva yang berubah dari normal bisa juga disebabkan oleh senyawa flavonoid yang masuk melalui siphon dan mengakibatkan kerusakan sehingga larva harus mensejajarkan posisinya dengan permukaan air dengan tujuan mempermudah larva dalam mengambil oksigen larva.

Tanin berperan sebagai racun pencernaan. Senyawa tanin diduga dapat mengganggu serangga dalam proses mencerna makanan dikarenakan tanin akan mengikat protein dalam sistem pencernaan yang dibutuhkan larva untuk pertumbuhan sehingga proses penyerapan protein dalam sistem pencernaan menjadi terganggu.

Selain itu, senyawa tanin akan menyebabkan penurunan aktivitas enzimprotease dalam mengubah asamasam amino. Senyawa tanin dapat mengikat enzim protease. Proses pengikatan enzim yang diikat oleh tanin 
menyebabkan kerja enzim tersebut akan menjadi terhambat,

sehingga proses metabolisme sel dapat terganggu dan larva akan kekurangan nutrisi. Sehingga akan berakibat menghambat pertumbuhan larva dan jika proses ini berlangsung secara terus menerus maka akan berdampak pada kematian larva.

Selain mengandung senyawa metabolit sekunder, berdasarkan penelitian Coelho dkk pada tahun 2009 mengunakan ekstrak aquades biji kelor mendapatkan biji kelor juga mengandung suatu senyawa peptida lectin bernama water-soluble lectin (WSMoL) yang dapat membunuh larva nyamuk Aedes aegypti. Senyawa ini juga memiliki kemampuan sebagai larvasida.

Mekanisme kerja senyawa watersoluble lectin (WSMoL) tidak sepenuhnya dipahami namun diduga karena penghambatan enzim glikosilasi pencernaan, yang mengikat reseptor glikosilasi pada permukaan sel epitel perut dan mengikat matriks peritrofik. Analisis mikroskopis pada larva Aedes aegypti instar IV yang mati menunjukan adanya perubahan morfologi berupa peningkatan lumen usus, adanya segmen yang mengalami hipertrofik, dan tidak adanya gambaran epitel dasar. Ketiadaan epitel dasar pada analisis mikroskop mengindikasikan bahwa aktivitas larvisida WSMoL disebabkan oleh kerusakan pada sistem pencernaan larva Aedes aegypti, sehingga larva akhirnya mati.

Pada penelitian ini penulis berasumsi bahwa senyawa metabolit sekunder yaitu alkaloid, saponin, tanin, dan flavonoid serta senyawa watersoluble lectin (WSMoL) dalam ekstrak biji kelor yang berperan sebagai larvasida terhadap kematian larva Aedes aegypti instar III/IV. Melalui mekanisme mengganggu proses pencernaan, metabolisme, dan mengganggu sistem saraf dan pernafasan larva.

\section{SIMPULAN DAN SARAN}

Ekstrak biji kelor (Moringa oleifera) memiliki efek larvasida terhadap larva Aedes aegypti instar III/IV jumlah kematian larva Aedes aegypti instar III/ IV pada Tabel 1 diatas memperlihatkan bahwa jumlah kematian larva tertinggi terdapat pada konsentrasi 1500 ppm yaitu sebanyak 15,66 ekor $(62,64 \%)$ sedangkan nilai terendah terdapat pada konsentrasi 500 
ppm dengan larva yang mati sebanyak 3,33 ekor $(13,32 \%)$.

Saran pada penelitian ini bisa dikembangkan dengan uji coba pada spesies larva nyamuk lain seperti Anopheles sp., Culex sp., dan Mansonia sp.

\section{DAFTAR PUSTAKA}

Ardianto T. Pengaruh Ekstrak Bunga Cengkeh (Syzygium aromaticum L.) terhadap Mortalitas Larva Aedes aegypti L. Skripsi. Universitas Sebelas Maret; 2008.

Aradilla A sikka. 2009. Uji Efektivitas Larvasida Ekstrak Ethanol Daun Mimba ( Azadirachta indica ) terhadap Larva Aedes aegypti. Universitas Diponogoro.

Bagavan A, Rahuman AA, Kamaraj C, Geetha K. Larvicidal activity of saponin from Achyranthes aspera against Aedes aegypti and Culex Quinque fasciatus (Diptera: Culicidae). Parasitol Res. 2008;103(1):223-9.

Prabhu K, Murugan K, Nareshkumar A, Ramasubramanian $\mathrm{N}$, Bragadeeswaran S. Larvicidal and repellent potential of Moringa oleifera against malarial vector, Anopheles stephensi Liston (Insecta: Diptera: Culicidae). Asian Pac J Trop Biomed. 2011;1(2):124- 9.

Cania E, Setyanimgrum E. Uji Efektivitas Larvasida Ekstrak Daun Legundi (Vitex trifolia) terhadap Larva Aedes aegypti. Med J Lampung Univ. 2013;52(4):52-60.

Kementerian Kesehatan. 2015. Profil Kesehatan Indonesia 2014. Vol. 51, Kementerian Kesehatan Republik Indonesia.

Kementerian Kesehatan. Modul Pengendalian Demam Berdarah Dengue. Kementerian Kesehatan. Direktorat Jenderal Pengendalian Penyakit dan Penyehatan Lingkungan; 2011.

Dinas Kesehatan Provinsi Nusa Tenggara Timur. Profil Kesehatan NTT. 2013.

Kardinan A. 2003. Tanaman Pengusir dan Pembasmi Nyamuk .Jakarta: Agromedia Pustaka.

Sastriawan A. Efektivitas Serai Dapur (Cymbopogon Citratus) Sebagai Larvasida Pada Larva Nyamuk Aedes Sp Instar III / IV. Skripsi Sarjana Kedokteran. Universitas Negeri Islam Syarif Hidayatullah; 2014.

Haditomo I. Efek Larvasida Estrak Daun Cengkeh (Syzygium aromaticum L) Terhadap Aedes aegypti L. Skripsi. Universitas Sebelas Maret; 2010.
Rattan RS. Mechanism of Action of Insecticidal Secondary Metabolites of Plant Origin. Vol. 29, Crop Protection. Elsevier Ltd; 2010. p. 913-20.

Rosmayanti K. Uji Efektivitas Ekstrak Biji Sirsak (Annona Muricata L.) Sebagai Larvasida Pada Larva Aedes Aegypti Instar III / 
IV. Skripsi Sarjana Kedokteran. Universitas Negeri Islam Syarif Hidayatullah; 2014.

\section{Rahayu SR. Kajian Potensi Biji Kelor (Moringa leifera) sebagai Koagulan. IPB (Bogor Agricultural University); 2011.}

Nepolean P, Anitha J, Renitta RE. Isolation, Analysis and Identification of Phytochemicals of Antimicrobial Activity of Moringa Oleifera Lam. Curr Biot. 2009;3(1):33-9.

Manurung PM. Uji Aktivitas Antibakteri Ekstrak Etanol Biji Kelor (Moringa oleifera Lam.) Terhadap Escherichia coli Dan Staphylococcus aureus. Universitas Sumatera Utara; 2106.

Coelho JS, Santos NDL, Napoleão TH, Gomes FS, Ferreira RS, Zingali $\mathrm{RB}$, et al. Chemosphere. 2009;77(7):934-8.

Gutierrez PM, Antepuesto AN, Eugenio BAL, Santos MFL. Larvicidal Activity of Selected Plant Extracts against the Dengue vector Aedes aegypti Mosquito. Int Res J Biol Sviences. 2014;3(4):23-32.

Kurniawan B, Rapina R, Sukohar A, Nareswari S. Effectiveness of The Pepaya Leaf (Carica Papaya Linn) Ethanol Extract As Larvacide For Aedes Aegypti Instar III. 2015;4:76-84.

Nindatu M, Tuhumury NL, Kaihena mArthaStudi P, Dokter P,
Pattimura U. Efektivitas Ekstrak Etanol Daun Sirih (Piper betle L.) terhadap Mortalitas Larva Nyamuk Anopheles sp dan Culex. J Kedokteran dan Kesehatan Molluca Med. 2011;4(1):88-105.

Gautam K, Kumar P, Poonia S. Larvicidal activity and GC-MS analysis of flavonoids of Vitex negundo and Andrographis paniculata against two vector mosquitoes Anopheles stephensi and Aedes aegypti. J Vector Borne Dis. 2013;50(3):171-8.

Tandi J. Pengaruh Tanin Terhadap Aktivitas Enzim Protease (Effect of Tannin on Protease Enzyme Activities) 2010;(1993):567-70.

World Health Organization and the Special Programme for Research and Training in Tropical Diseases (TDR). Dengue: guidelines for diagnosis, treatment, prevention, and control. Special Programme for Research and Training in Tropical Diseases. 2009.

WHO Regional Office for South- East Asia. Comprehensive Guidelines for Prevention and Control of Dengue and Dengue Haemorrhagic Fever. 2011.

World Health Organization. Dept. of Communicable Disease Prevention Control and Eradication. Guidelines for Laboratory and Field Testing of Mosquito Larvicides. Geneva : World Health Organization; 2005. 